\title{
RUANG, LINGKUNGAN DAN WILAYAH: SUATU KONSEP DASAR GEOGRAFI
}

\author{
Oleh: Dilahur
}

\begin{abstract}
Geographic development bistory has made five influential point of vien in the development of geographic concepl, i.e; delerminison concepl from Friedrich Ratzel, "possibilism" concept from Paul Vidal de La Plache, Time and landscape concept fiom Sauer, regional concept from Hartshorne, and spatial concept fiom schacfer: These point of vien created Three main approach in modern geography i.e: spatial approach; ecological upproach; and regional approach. Study of these point of view as a totality point of view or geograpbical approach. Time as fourth dimension in geography therefore, each problems have to be viewed from aspects of spatial dynamics; ecologial dynamics; and regional dynamics.
\end{abstract}

\section{INTISARI}

Sejarab perkembangan geografi mencatat lima sudut pandang yang berpengarub luas dalan perkembangan pemikiran geografi yaitu, delerminisme dari Friedrich Ratzel, pessibilisme dari l'aul Vidal de la Blache, waklu dan bentang lahan dari Sauer, studi wilayab dari llartsbonne dan keruangan dari Scbaefer.

Kelima sudut pandang tersebut melabirkan tiga pendekatan utama dalam geografi saat ini yaitu sudut pandang kerwangan, sudul pandang lingkungan dan sudut pandang kompleks wilayab. P'embabasan tentang bakekal ruang, lingkungan dan wilayah menunjukkan babwa ketiga sudut pandang terset)ul merupakan satu kesatuan sudul pandang atau pendekatan geografi. Waktu merupakan dimensi ke empat dalam geografi oleb karenanya setiap permasalaban barus dilihal dari segi dinamika keruangan, dinamika lingkungan dan dinamikan kompleks wiluyab.

\section{Perkembangan Pemikiran Geografi}

Sejarah perkembangan geografi mencatat lima orang tokoh pemikir yang berpengaruh luas dalam perkem. bangan pemikiran tentang paradigma atau kerangka keilmuan. Pemikiran tersebut berisi pandangan mendasar sebagai acuan, tema-tema pokok, teoriteori dan metode-metode dalam geografi.

Kelima tokoh tersebut bescrta po. kok-pokok pikirannya sccara ringkas (ringkasan dari tulisan Milton I: Ilar. vey dan Brian P. Holly, 1981: 21 - 301) scbagai berikut:

1. Friedrich Ratzel

Scorang doktor di bidang zoologi, geologi dan anatomi komparatif yang telah mempengaruhi perkem. bangan geografi melalui bukunya Antropogeography (1882). Dalam buku tersebut ia berpandangan bahwa geografi sebagai hubungan 
antara ilmu-ilmu kealaman dan studi tentang mantisia. T'ema pokok dari pemikirannya adalah lingkungan organik mengontrol atau mendominasi sedangkan manusia (organisme) hanya memberikan respon atau teori determinisme lingkungan. Pendekatan-pendekatan untuk memahami obyek dipinjam dari ide Darwin yaitu metode deduktif, dan konsep dari Newton yaitu sebabakibat dan pendekatan sistematik. Paradigma Ratzel adalah detcrminisme,

2. Paul Vidal de La Blache menentang terhadap pemikiran Ratzel yang terlalu memberi peranan besar kepada lingkungan, sehingga meniadakan inisiatif dan kemampuan memilih, memperbaharui dan kreatifitas manusia. Vidal meminimalkan pengaruh lingkungan. Melalui karyanya yang terbesar Tableau de La geographie de la france (1903) disamping La France de l'cst (1917) dan Principles de Geographic Humaine (1922), Vidal scbagai ahli sejarah memunculkan Paradigma possibilisme. Tema pokok yang dikemukakannya bahwa perubahan-perubahan dari nilai sikap dan kebiasaan tclah menciptakan kemungkinankemungkinan untuk komunitas manusia. Konsep-konsep yang mendasari geografi sosial yang clikembangkannya adalah trilogi miliau (lingkungan), genre de vie (gaya hidup) clan sikurlasi (interaksi antara berbagai tempat di bumi). Dari padanya lahir teori genre devie: produk dan refleksi dari hubungan timbal balik antara manusia dan lingkungannya. Vidal terlalu menekankan pada suatu region/wilayah dan untuk mempelajarinya metode yang digunakan adalah kerja lapang atau studi kasus dan menekankan sebab. sebab yang berangkaian alau ber. urutan.

\section{C.O. Sauer}

Selama tahun 1919 - 1922 melalui empat buah papernya yaitu Economic problems of the Ozark Highlands of Missouri (1919), Gcography as Regional economic (1920), Problems of Land Classification (1920) dan Obyectives of Geographic Study (1922) yang kemudian dikembangkan secara penuh melalui bukunya The Morphology of Landscape (1925), suatu pandangan bahwa peran pakar geografi menyelidiki dan memahami sifat perubahan dari bentang alami ke bentang budaya dan taraf perkembangan secara berurut-turut yang telah dilalui oleh benteng budaya selama perubahan tersebut. Sedang melalui tulisannya foreword to His. torical Geography (1941), Agricultural Orgigins and Dispersals (1952) dan The Farly Spanish Main (1966), ia mengembangkan kerang. ka kerja sejarah untuk mempelajari perkembangan bentang lahan dengan fokus pola tempat tinggal manusia lebih daripada kekuatan sosial budaya dalam mempengaruhi/. membuat pola tersebut.

Inti pandangan Saucr adalah waktu merupakan dimensi keempat dalam geografi atau pandangan sejarah dan bentang lahan adalah sudut pandang geografi. Sauer meno. lak pandangan differensiasi wilayah. Dari pandangan tersebut lahir teori bentang lahan budaya berkembang dari bentang lahan fisikal dan manusia sebagai pelaku modifikasi lingkungan. Metode ilmiah yang dikembangkannya adalah kerja lapangan, rekonstruksi kesejarahan 
terhadap bentang lahan manusia dan perkembangan induktif polapola bentang lahan.

4 Richard Hartshorne

Berbeda dengan Sauer yang me. nolak pandangan differensiasi wilayah, Hartshorne justru menckankan pada studi wilayah atau sudut pandang khorologi dan pemahaman idiografik. Melalui bukunya yang kemudian sangat berpengaruh $\mathrm{Na}$ ture of Geography (1961) dan Perspective on the Nature Geography, ia menyatakan bahwa tujuan sudut pandang khorologis adalah untuk mengetahui karakter wilayah-wilayah dan tempat-tempat melalui keseluruhan yang adanya bersama dan interelasi antar kemampuan yang berbeda dari realita dan variasi perwujudannya, dan untuk me. mahami permukaan bumi sebagai suatu kescluruhan dalam susunan aktualnya dari benua-benua, wilayah-wilayah besar dan kecil dan tempat-tempat. Hartshorne juga menentukan perbedatan wilayah untuk mencirikan cara dalam mana para geofraf berkaitan dengan variasi yang luas dari gejala-gejala fisik, ckonomi dan sosial yang adanya bersama-sama di dacrah tertentu dan membedakannya dengan daerah-daeah lainnya. Hartshorne menyarankan penggunaan dua pendekatan idiografik dan nomologik dan metode yang digunakannya adalah kerja lapang dan pemetaan Teori yang clihasilkannya adalah tentang hubungan timbal-balik antar wilayah dan tingkatan klasifikasi wilayah.

5. F.K. Schaefer

Schaefer menyerang exceptionalisme di geografi dan menyarankan statu geografi yang lebih no. motetik dan didasarkan atas tecriteori kcruangan atau dengan kata lain kcruangan sebagai sudut pandang geografi. Melalui bukunya Exceptionalisme in geography ia kemukakan tiga tema utama, dalam geografi yaitu interaksi keruangan, organisasi keruangan dan pertimbangan/perbandingan nomotetik. Teori-tcori yang dikembangkannya meliputi teori-teori tentang lokasi, arus/aliran, distribusi keruangan dan pemukiman. Sedangkan metode yang digunakan meliputi metode matcmatik, statistik dan motode ilmu pengetahuan.

Secara diagramatis perbandingan clari tcma-tema pokok, teori \& hukum, metode dan kclemahan pandangan kclima tokoh tersebut dapat dilihat padat tabel berikut (lihat ' label 1)

Dari uraian tersebul di atas nam. pak ada perubahan pandangan $t<n$. tang paracligma geografi, tekanan pada bentang lahan digantikan olch wilayah, dan geografi disarankan menggumakan pendekatan keruangan. Namun menurut Bintarto (1984:86) ada inti yang masih tctap konsisten yatu the reciprocal rela. tionship between man and earth or environmental sebagai jiwa geo grafi.

Bintarto (1983:85) menyimpulkan dari definisi atau pandangan berbagai ahli bahwa ternyata mere. ka banyak yang memperhatikan:

a. Bumi sebagai tempat tinggal

b. Hubungan manusia dengan ling. kungan

c Dimensi ruang dan dimensi his. toris

d. Pendekatannya, spatial, ckologi, regional

Persoalannya adalah tigat pendekat. 
an geografi yaitu pendekatan keruangan, pendekatan lingkungan dan pendekatan kompleks wilayah tersebut masing-rmasing berdiri sendiri, saling melengkapi atau merupakan satu kesatuan cara pandang. Untuk itu perlu pembahasan hubungan antara konsep ruang, lingkungan dan wilayah.

\section{Konsep Ruang dan Isinya}

Berbicara tentang ruang pertama dapat dari segi konsepsinya, bentuknya, ukurannya atau fungsinya dan yang kedua dapat dibicarakan sesuatu di clalam ruang.

Beberapa pengertian kntang ruang akan dikemukakan di sini (diambil dari bahan kursus SEPADYA, 1987:4).

Ruang sebagai wadah, diterjemahkan dengan "ruimtc" (Bclancla), "Raum" (Jerman), "Space" (Inggris), "Spatium" (Latin), mula-mula diartikan bidang datar (Planum, planologi). Dalam perkembangan selanjutnya mempunyai dimensi 3 (tiga) dan berarti "tempat tinggal" (dwelling house). Dalam arti planologis materialnya, berarti "tempat pemukiman" yang harus ditata sebaikbaiknya, demi kebahagiaan, kesejahteraan dan kelestarian umat manusia (II. Moeftie Wirjodihardjo, SHI).

Ruang sebagai pengertian (conception) terdiri dari unsur-unsur bumi, air, (sungai, danau dan lautan) dan udara (ruang angkasa diatasnya dan segala kekayaan didalamnya), mempunyai tiga dimensi. Space (latin, spatium) is a distance extending without limit in all directions, that which is thought of as boundiesss; continous exspance extending in all directions or in three dimensions, within which all material things are contained. (Webs. ter's New World Dictionary).
Ruang adalah bagian dari alam. yang merupakan wadah atau tempat, yang di dalamnya terdapat ataupun tidak terdapat, satu atau lebih zat atau materi dan perubahan. Sebagai contoh adalah ruang dibagian dalam sebuah gelas yang dapat berisi air, dapat pula berisi pasir atau udara, atau laba-laba hiclup yang merayap-rayap. Tetapi dapat juga dibuat hampa (Direktorat Jendral Cipta Karya, 1986:2).

Dari pengertian di atas dapat dipertanyakan ruang tersebut konsepsi atau benda kah? Bila ruang tersebut konsepsi berarti dibicarakan hakekat ruang dan bila benda/wujud berarti di. bicarakan bentuk, ukuran dan fung. sinya atau dari segi kepentingan praktis.

Ruang pada hakekatnya lebih sebagai suatu batas-batas tiga dimensional. Dimanakah batas-batas tersebut, atau seberapa ukuran, bagaimana bentuknya, berfungsi atau tidak ruang tersebut bukan persoalan. IJal tersebut menjadi persoalan bila ruang dipandang sebagai benda/wujud bagi kepentingan praktis. Sebagai contoh ruang nasional memiliki batas-batas daratan/lautan- angkasa-kedalaman tertentu.

Ruang dalam arti benda/wujud adalah suatu batas-batas tiga dimensional dengan ukuran, bentuk dan fungsi tertentu. Ukuran, bentuk dan fungsi ini ditentukan oleh tujuan baik ilmiah maupun praktis dari yang berkepen. tingan. Dalam arti ilmiah dapat dikemukakan sebagai contoh pengertian ruang fisik dan ruang sosial.

Physical Space (ruang fisik) merupakan suatu wadah dari segala benda (hidup atau mati) atau merupakan suatu wadah dari berbagai sistem kehidupan dan komponen alam dan non alam. Social space (ruang sosial) diar- 
an sebagai suatu sintesa dari dimen$s$ perscpsi dengan dimensi obycktif serhadap ruang (space). Ujud ruang aerscbut dapat physical landscape fbentang fisik), social landscape (ujud sosial) dan cultural landscape (benang budaya) (Bintarto, materi kuliah program Geografi Fakultas Pasca Sar. fana UGM, 1991). Dalam arti praktis dapat dikemukakan pembagian ruang perkotaan atau tata ruang perkotaan, pembagian ruang nasional menjadi satuan wilayah pembangunan atau seperti pada definisi yang pertama dan sebagainya.

Scperti telah dikemukakan di atas ruang sebagai wadah inerupakan tempat benda (hidup atau mati), oleh karena itu sesuatu di dalam ruang mempunyai kcberadaan tertentu baik terhadap ruang itu sencliri maupun terhadap keberadaan sesuatu yang lain.

Sesuatu secara individu mempunyai letak absolut diruang, dan letak relatif terhadap sesuatu yang lain. I.celak scsuatu memberikan kepaclanya posisi dan posisi mempunyai konsekuensi peranan baik absolut maupun relatif. I.c. tak Indonesia suatu misal letak absolutnya telah memberikan konsckucusi iklim musim yang berbeda dengan wilayah lain di bumi, sedang letak relatifnya dalam posisi silang memberikan peranan strategis dalam percaturan dunia.

Hubungan letak antar individu di dalam ruang selain mempunyai perbedaan posisi dan peranan jugat mengandung konsekucnsi jarak baik absolut maupun relatif. Jarak absolut adalah jarak terukur sedang jarak relatif adalah jarak perbandingan dari berbagai jarak. Misalnya jarak antara kota Surakarta dan Yogyakarta $65 \mathrm{~km}$ sedangkan Semarang lebih jauh dari Yogyakarta dibandingkan Surakarta.
Ilubungan letak individu yang sejenis sccara kescluruhan discbut distribusi atau persebaran. Dalam perscbaran antar inclividu sejenis dapat ditentukan polanya, luas atau volumenya, kepadatan dan strukturnya. Hubungan antar persebaran berbagai kelompok individu sejenis akan menghasilkan sistem keruangan.

\section{Lingkungan : Hubungan Antar Isi Ruang}

1)ari urian tentang ruang clapat difahami bahwa berbagai bencla dan makhluk hiclup atau kelompok benda atau kelompok makhluk hidup bersama-sama berada di clalam ruang yang sama. Keberaclaan bersama terscbut bukan keberadaan yang saling terpisah dan saling asing, tetapi terclapat suatu tata hubungan yang memiliki suatu ketcraturan yang relatif yang dinamakan lingkungan.

$\Lambda$ da cluat istilah yang scring digunakan clalam pembahasan tentang kcberaclaan bersama antar isi ruang ini yaitu lingkungan (cnvironment) dan ckologi.

Istilah ekologi untuk pertama kali dipakai oleh llacekel seorang ahli $z o()$ logi Jerman di tahun 1864, scjak tahun 1893, ekologi tumbuhan dan ekologi hewan berkembang sendiri-sendiri, kemudian dirasakan manfaatnya un. tuk dikcmbangkan bersama-sama. Dari scjak itu pula manusia scbagai salah saIu unsur dari organisme hiclup mulai ditonjolkan dalain ckologi. Olch kitrena itu ekologi mencakup interaksi antara organisme hidup dengan lingkungannya (Bintarto, 1979:19).

Menurut Strahler (1977:14). Lingkungan (environmental) diclefinisikan secara sangat umum schagai "segala sesuatu yang mengclilinginya" yang dibu- 
tuhkan suatu obyek pencrima. Apakah yang dikelilingi? Dikelilingi oleh apa" Awalnya, perhatian semua pakar geografi terhadap lingkungan dari manusia. Tetapi manusia tidak dapat berada atau difahami terpisah dari bentukbentuk lain dari kehidupan binatang dan dari kehidupan tumbuhan. Kemudian, kita harus menghadapi lingkungan dari semua bentuk kehidupan termasuk lapisan hubungan kehidupan, atau biosfer dari planet bumi. Lapisan hiclup yang tipis terletak pada atau ter. tutup oleh saling hubungan penting antara komponen bumi utama: atmosfer (komponen gas), hidrosfer (komponcen air), dan lithosfer (komponen mineral padat).

Sedang organisme apakah clari satu spesies atau beberapa, apakah ter. masuk kerajaan tumbuhan atau kerajaan hewan, saling hubungan tidak hanya dengan lingkungan fisikal yang menjadi tempat tinggalnya, tetapi dengan lainnya juga. Studi interaksi ini dalam bentuk pertukaran materi, energi dan pendorong berbagai jenis - antara bentuk-bentuk kehidupan dan lingkungan adalah ilmu ekologi, yang didefinisikan sangat umum. Kumpulan total komponen berinteraksi dengan suatu kelompok organisme discbut suatu sis- tem ekologi atau dengan singkat ekosistem.

Pada ekologi penekanan lebih pada aliran materi, energi dan stimuli dalam ekosistem dengan makhluk hidup dipusatnya, sedang lingkungan lebih pada pola hubungan antar lapisan atau sphera dalam kesatuan geosfer. Dalam hal ini fokus studi dapat saja pada komponen abiotik atau fisik seperti studi lingkungan topografi karst. Pola hubungan ini dapat berupa interrelasi, interaksi, interdependensi, integrasi, assosiasi dan seterusnya.

\section{Geosfer sebuah konsep lingkungan.}

Obyek material yang umum dan luas dari geografi, yaitu geosfer yang - meliputi: litosfer, atmosfer, hidrosfer, biosfer, pedosfer, antroposfer yang kcmudian dapat menimbulkan studi kekhususan, dan ini dipandang wajar (Bintarto, 1983:4). Geosfer tersebut mcrupakan suatu kesatuan sistem bagian dari sistem alam semesta. Komponcn-komponen geosfer tidak dapat dipisahkan satu dengan lainnya karena jalinan saling pengaruh dan saling tergantung. Prof. Drs. H. R. Bintarto menggambarkan dengan baik alam semesta beserta falsafahnya. 


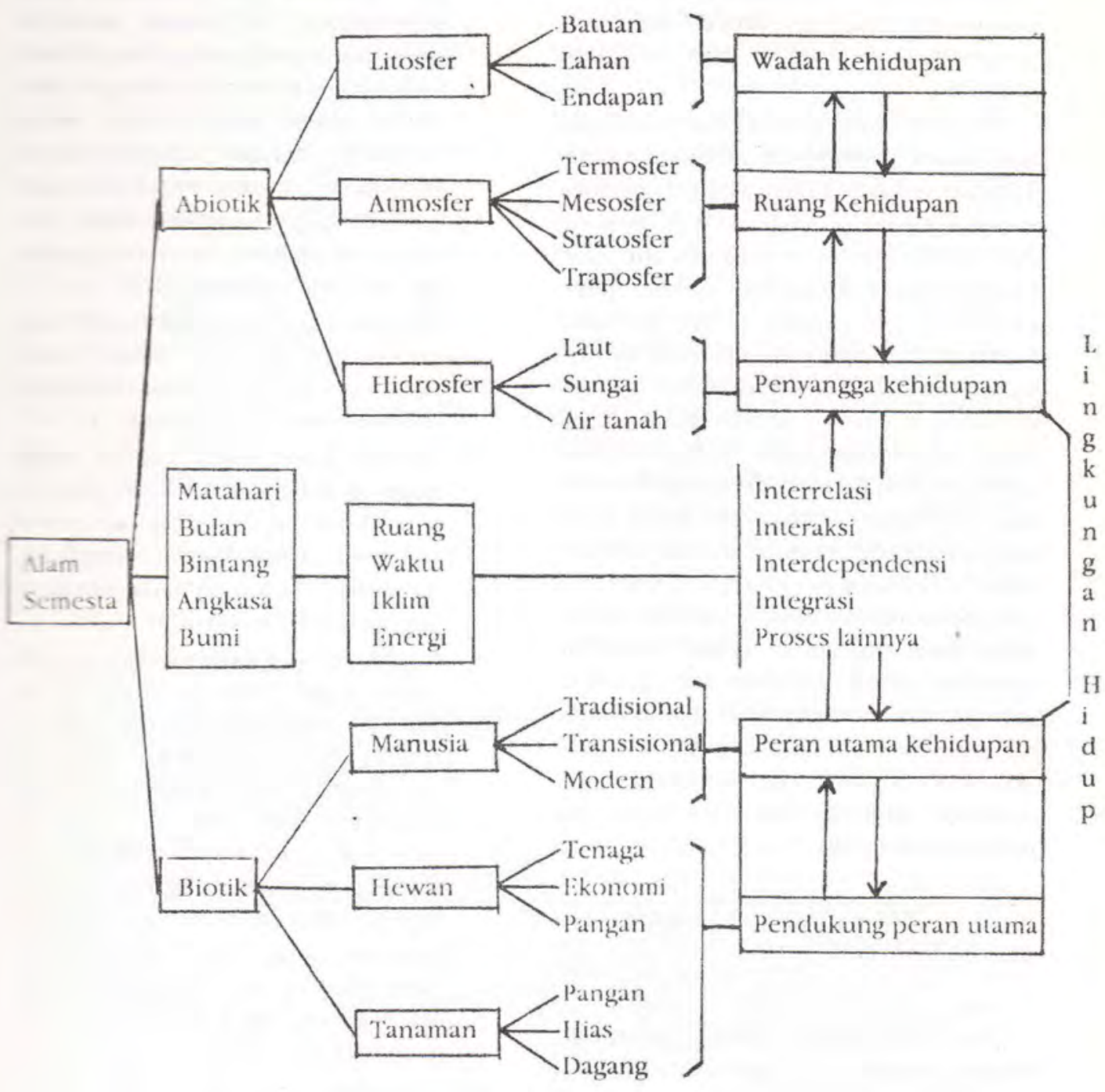

Bintarto, materi kuliah program Geografi Pasca Sarjana UGM., 1991.

Hubungan saling pengaruh dan saling ketergantungan antar komponenkomponen geosfer dapat dipelajari melalui berbagai model seperti siklus hidrologi dalam komponen hidrosfer yang melibatkan komponen lain yaitu atmosfer dalam proses hujan, litosfer dan hidrosfer baik dalam air per- mukaan maupun air tanah, biosfer dan antroposfer sebagai pengguna dan penyebab perubahan keseimbangan dalam siklus hidrologi tersebut. Keseimbangan siklus hidrologi akan berubah bila misalnya terjadi penggundulan hutan dan selanjutnya akan mempengaruhi proses-proses geomorfik seperti erosi, perubahan landform, kesuburan 
tanah dan selanjutnya akan berpengaruh terhadap kehidupan yaitu turun. nya produktifitas, kcpunahan species, kemiskinan, kekacauan dan seterusnya.

Dalam konsep geofer, manusia atau komponen antroposfer memang harus ditekankan pada posisi sentral, berhubungan kemampuannya untuk bertindak secara rasional dan kreatif, sehingga dapat berperan dalam perubahan keseimbangan sistem geosfer. Berbagai tindakan manusia telah mengancam kehidupan secara keseluruhan misalnya konsumsi bahan bakar fosil yang berlebihan telah menimbulkan kekhawatiran adanya effek rumah kaca dan berbagai bahan kimia inisal cluroflourocarbon telah mcmbuat lapisan ozon berlubang, penebangan hutan secara besar-besaran dikhawatirkan akan mengubah iklim sccara dratis. Olch karena itu untuk melestarikan geosfer sebagai sistem lingkungan dimana manusia termasuk di dalamnya dan berpe. ran sentral maka agama sebagai pengendali perilaku manusia memiliki peran sentral pula

Wilayah: Ruang Dengan Lingkungan Berciri Tertentu

Konsepsi wilayah sampai sekarang belum dicapai suatu pengertian yang sama, hal ini disebabkan latar belakang disiplin dan kepentingan yang berbeda-beda. Pada kesempatan ini dikemukakan beberapa definisi untuk memperoleh pemahaman komponen wilayah.

1. Region/Wilayah secara umum clapat diartikan sebagai sebagian permu. kaan bumi yang dapat dibedakan dalam hal-hal tertentu dari daerah sekitarnya (Bintarto dan Surastopo Iladisumarno, 1979:26).
2. Didasarkan kepada pendekatan sistem tcrutama dan khususnya yang menyangkut hubungan interaksi dan interdependensi antara subsis. tem utama ecosystem dengan sub. sistem utama social system, serta kaitannya dengan wilayah-wilayah lainnya dalam membentuk kesatuan wilayah guna pengembangan, terutama penjagaan kelestarian wilayah tersebut (Sutami, 1977:....)

3. Wilayah adalah sebutan untuk ling. kungan permukaan bumi pada umumnya dan tentu batas-batasnya (Purnomosidi Hadjisaroso:...)

4. Wilayah yaitu suatu bagian ruang buini di dalamnya terdapat bentuk. bentuk tertentu dari keadaan sosial ekonomis penduduknya scbagai penyesuaian hidup kcpada keadaan alamnya (lih Abclurrohim 1974:....)

5. Region yaitu wilayah yang memiliki karakteristik tertentu yang khas, yang membedakan diri dari regionregion lain disekitarnya. Region ini merupakan wilayah geografi yang ukurannya bervariasi dari yang sangat luas sampai yang terbatas. Karakter terpenting yang harus dimilikinya yaitu memiliki homogenitas tertentu yang khas. Karakteristik yang khas ini dapat berupa aspek fisik maupun aspek kultural (Nursid Sumaatmadja, 1981:....)

6. A region is section of the earth's surface marked by an overriding sameness or homogcinity (Harm J. de $B l i j, . . . . . . .$.

Dari beberapa definisi cli atas dapat diambil pokok-pokok atau komponen dari wilayah yaitu:

- Ruang permukiman bumi dengan batas tertentu

- Unsur-unsur wilayah baik alam maupun manusia

- Interaksi dan interdependensi antar 
Ensur wilayah dan

carakteristik tertentu.

tolam memaham suatu wilayah - bimya dilihat sebagai suatu komcickes unsur-unsurnya dan dilihat $4=2=$ kompleks wilayah atau hubung- ara dengan wilayah-wilayah lain. Een komponen wilayah tersebut terlifet bitan antara ruang dengan ling. kum. dimana lingkungan yang dirakud adalah geosfer yang merupaan sistem hasil interaksi dan interdeperadensi atmosfer, litosfer, pedosfer, tedrosfer, biosfer dan antroposfer. staz dengan kata lain, geosfer pada ruang permukaan bumi dengan batas ecruentu aclalah wilayah.

Tiza Pendekatan Geografi Sebagai Satn Kesatuan

Dalam Geografi terpadu (integrated exography) untuk menckekati atau menghampiri masalah dalam geografi dogunakan bermacam-macam pendesatan atau hampiran (approach) yaitu pendekatan analisa keruangan (spatial analysis), analisis ekologi (coological analysis) clan analisis kompleks (region) complex analysis) (Bintarto dan Surastopo Hadisumamo, 1979:12). Seperti telah dipertanyakan di depan ketiga penclekatan tersebut apakan masingmasing berdiri sendiri, saling melengkapi atau satu kesatuan cara pandang.

Heslinga (1975) dalam Bintarto (1983:5) menyatakan acla 3 hal yang pokok dalam mempelajari obyck formal dari sudut pandang keruangan yaitu:

1. Pola clari scbaran gejala tertentu di muka bumi (spatial pattern)

2 Keterkatan atau hubungan scsama antar gejala terscbut (spatial systcin).
3. Perkembangan atau perubahan yang terjadi pada gejala tersebut (spatial processes)

Dari ketiga sudut pandang ke ruangan terscbut, yang pertama pola keruangan clari satu gejala, yang kedua keterkaitan pola keruangan clari berbagai gejala, sedang yang ketiga hal tersebut dikaitkan dengan wakı. Berbeda dengan keterkaitan keruangan atau spatial system, pada pendekatan lingkungan keterkaitan tersebut dicari nilai hubungannya dan dapal diketahui kuat lemahnya hubungan saling pengaruh dan saling tergantung, schingga dapat diketahui faktor paling berpengaruh terhadap suatu permasalahan di suatu tempat. Dari sini akan diketahui berbagai daerah yang dari segi keruangan relatif sama, telap)i dari scyi lingkungan mempunyai perbedatan fitktor dominannya.

Kombinasi antara analisa keruangan dan analisa ckologi discbut analisa kompleks wilayah (Bintarto dan Suras(op) Hadisumarno, 1979:24). Hal ini dap̧at dijelaskan bahwa sclelah ketcr. kaitan antar sebaran keruangan clari borbagai gejala dikctahui maka akan diperoleh berbagai wilayah clengan ciri yang berbeda-beda. Selanjumya wilayah yang bercirt sama ditcliti clari segi lingkungan dan akan diperolch berbagai pembagian wilayah yang lebih banyak lagi. Dari wilayah yang dihasilkan dapat dipelajari hubungan antar wila. yah terebut. Pada saat ini dengan tek. nik sistem Informasi geografi dapat dilakukan Overlay peta penyebaran gejala-gejala di muka bumi dalan jumlah yang cukup besar.

Dari uraian tersebut di atas penulis berpenclapat ketiga pendekatan yaitu pendekatan keruangan, pendekatan lingkungan dan pendekatan kompleks wilayah merupakan satu kesaluan pen- 
dekatan geografi yang membedakan dari disiplin lain. Geografi tidak hanya memandang dari segi ke ruangan saja, lingkungan saja atau dari segi kompleks wilayah. Langkah-langkahnya dimulai dari pendekatan ke ruangan dan diperoleh pola sebaran berbagai gejala atau faktor yang kemudian dioverlaykan, maka diperoleh pembagian wilayah. Langkah berikutnya mengkaji pada bagian wilayah-wilayah yang dari segi lingkungan atau nilai interaksi dan interdependensi faktorfaktor atau gejala-gejala tersebut, misalnya klas kemampuan lahan sama tetapi faktor dominannya berbeda. Dari sini akan diperoleh pembagian lebih lanjut wilayah yang sama. Lang. kah berikutnya adalah mengkaji dari segi kompleks wilayah tcrutama hubungan antar bagian wilayah tersebut.

Dengan demikian hasil akhir kajian geografi adalah hasil kajian kompleks wilayah yang dapat digunakan untuk regional forecasting dan regional plan. ning.

Waktu Memberi Nilai Dinamis Terhadap Pendekatan Geografi

Seperti dikemukakan di depan Saucr telah memasukkan waktu sebagai dimensi keempat dalam geografi, waktu dapat diartikan sebagai gerak, perubahan, proses dan sebagainya. Ditinjau dari dimensi waktu, maka sesuatu dalam ruang dapat mengalami perubahan letak absolutnya dan akibatnya berubah pula letak relatif atau posisinya dan selanjutnya merubah peranannya maupun peran sesuatu yang lain.

Perubahan ini dapat juga meliputi perubahan pola persebaran, struktur keruangan, ukuran-ukuran seperti ja- rak, luas, volume dan sebagainya. Contoh dalam hal ini dapat dikemukakan jarak absolutnya tetap tetapi secara re. latif berbeda karena pemakaian trans. portasi yang berbeda seperti dokar, sepeda, kendaraan bermotor, pesawat terbang dan sebagainya. Dibangunnya prasarana jalan di suatu daerah yang semula terpencil akan merubah letak, posisi dan peranan relatifnya.

Dimensi waktu dalam konteks ling. kungan, maka akan berubah pola hubungan, struktur dan proses yang terjadi pada sistem lingkungan. Misalnya pemakaian bahan bakar fosil yang ber. lebihan, penggundulan hutan, introduksi teknik-teknik pertanian baru, eksploatasi berbagai sumberdaya mineral, dari waktu ke waktu dapat memberikan perubahan ukuran, karakteristik, bentuk, peran dan tingkat perkem. bangan wilayah.

Oleh karena itu dalam studi geografi setiap permasalahan hendaknya dilihat pula dari segi dinamika ke ruangan, dinamika kelingkungan dan dinamika kompleksitas dan kompleks wilayah

\section{Penutup}

Perkembangan geografi ditandai oleh perubahan pandangan terhadap pendekatan atau sudut pandang, namun ada yang tetap yaitu hubungan timbal-balik antara manusia dengan lingkungan. Lingkungan bagi para geograf adalah geosfer yang merupakan hubungan timbal balik antara atmosfer, litosfer, pedosfer, hidrosfer, biosfer dan antroposfer.

Dari tinjauan tentang ruang, lingkungan dan wilayah maka pendekatan atau sudut pandang geografi merupakan satu kesatuan dari pendekatan keruangan, pendekatan lingkungan 
than pendekatan kompleks wilayah. Pakar geografi tidak dapat melepaskan dini dari dimensi waktu dalam kajian$m^{2}$, oleh karena itu gejala-gejala atau permasalahan hendaknya dilihat dari sudut pandang dinamika keruangan, dinamika lingkungan dan dinamika kompleks wilayah.

\section{DAFTAR PUSTAKA}

Bintarto, R. dan Surastopo, 1979. Metode analisa Geografi, Jakarta; LP3ES

Buntarto, R, 1984. Urbanisasi dan Permasalahannya, Jakarta, Ghalia Indonesia.

- 1987. Perkembangan Pemikiran Geografi, Lokakarya Mensatubahasakan Konsep dan Pemikiran Geografi, Yogyakarta, Fak. Geografi, UGM.

_ 1991 Materi Perkuliahan Program Geografi Fakultas Pasca Sarjana UGM, Yogyakarta.

Bhij. Harm J. de, .... Geography Regional and concepts, Student Study guide and Glassory, New York, John Wilcy and Sons Inc.

Direktorat Jendral Cipta Karya, 1985. "Perencanaan Tata Ruang Kota dan Daerah" Disajikan pada Forum Diskusi Tata Guna Tanah Sehubungan dengan Perencanaan Pembangunan di Daerah Jakarta, 3-5 Desember 1985.

Harvey, M.E and Holly, Brian P., 1981. Themes in Geographic Thought, London, Croom Helm.

Iih Abdurrachim, 1974. Perancangan Regional, Dasar-dasar pemikiran dan Analisa Sistem Penyusunan, Bandung, Team Penasehat Ahli BAPPEMDA JABAR.

Nursid Sumaatmodjo, 1981. Studi Geografi Suatu Pendekatan dan analisa keruangan, Bandung, Penerbit Alumni.

Poernomosidi Hadjisaroso, .... Konsepsi Dasar Pengembangan Wilayah di Indonesia, Jakarta, Departemen Pekerjaan Umum, Cetakan ke dua.

Strahler, Alan H. and Strahler, Arthur N., 1977. Geography and Man's Environment, New York, John Wiley and Sons.

Sugeng Martopo dkk, 1987. Pembangunan Wilayah Berwawasan Lingkungan, Bahan Khusus untuk Kursus SEPADYA.

Sutami, 1977, " Ilmu Wilayah Implikasi dan Penerapan Dalam Pembangunan di Indonesia", Musyawarah KAGAMA II di Surabaya 
GEOGRAPHIC EXEMPLAR AND THEIR ASSOCLATED ATTRIBUTES

\begin{tabular}{|c|c|c|c|c|c|}
\hline AUTHOR & EXEMPLAR & $\begin{array}{l}\text { IMAGE OF SUBJECT MAT- } \\
\text { TER }\end{array}$ & THEORIES \& LAW & METHODS & AREA OF DISCOUNTENT \\
\hline RATZEL & Anthropogeography & $\begin{array}{l}\text { Inorganic control organic } \\
\text { response }\end{array}$ & $\begin{array}{l}\text { Darwinism (stage theo- } \\
\text { ries of physical \& social } \\
\text { system) } \\
\text { Environmental deter- } \\
\text { minism }\end{array}$ & $\begin{array}{l}\text { Deductive } \\
\text { Newtonism } \\
\text { Cause \& effect }\end{array}$ & $\begin{array}{l}\text { Too much environmental } \\
\text { control } \\
\text { Absence of human initiati- } \\
\text { ves \& choice: eliminated } \\
\text { novelty \& creativity }\end{array}$ \\
\hline VIDAL & $\begin{array}{l}\text { Tableau de la Geo- } \\
\text { graphie de la France }\end{array}$ & $\begin{array}{l}\text { Changes is attidudes Value } \\
\text { and habits create posi- } \\
\text { bilities or human commu- } \\
\text { nities. }\end{array}$ & $\begin{array}{l}\text { Genre de vie: the pro- } \\
\text { duct \& reflection of the } \\
\text { interrelation between } \\
\text { man and his environ- } \\
\text { ment }\end{array}$ & $\begin{array}{l}\text { Field work/case stu- } \\
\text { dies } \\
\text { Emphases on cau- } \\
\text { sal successions or } \\
\text { sequences }\end{array}$ & $\begin{array}{l}\text { Too much emphases on a } \\
\text { region }\end{array}$ \\
\hline SAUER & $\begin{array}{l}\text { The four 1919-1922 } \\
\text { papers } \\
\text { Morphology of Land- } \\
\text { scape }\end{array}$ & $\begin{array}{l}\text { Time the fourth dimension } \\
\text { in geography }\end{array}$ & $\begin{array}{l}\text { Cultural landscape } \\
\text { evalve from the phy- } \\
\text { sical landscape. }\end{array}$ & $\begin{array}{l}\text { Field work \& histo- } \\
\text { rical reconstruction } \\
\text { of the human lands- } \\
\text { cape }\end{array}$ & $\begin{array}{l}\text { Pre-occupation with pattern } \\
\text { rather than process }\end{array}$ \\
\hline & $\begin{array}{l}\text { Agricultural Origin \& } \\
\text { Dispersals The Early } \\
\text { Spanish Main }\end{array}$ & $\begin{array}{l}\text { Landscape view of geog- } \\
\text { raphy }\end{array}$ & $\begin{array}{l}\text { Man as an agent of en- } \\
\text { vironmental modifica- } \\
\text { tion }\end{array}$ & $\begin{array}{l}\text { Inductive develop- } \\
\text { ment of landscape } \\
\text { pattern }\end{array}$ & $\begin{array}{l}\text { The inability to analysis } \\
\text { societal value, believes and } \\
\text { social organization. }\end{array}$ \\
\hline HARTSHORNE & $\begin{array}{l}\text { Nature of Geography } \\
\text { Perspective on the Na- } \\
\text { ture Geography }\end{array}$ & $\begin{array}{l}\text { Chorology } \\
\text { Perceived as idiography }\end{array}$ & $\begin{array}{l}\text { Functional relationship } \\
\text { Order clasifications }\end{array}$ & $\begin{array}{l}\text { Field work } \\
\text { Mapping }\end{array}$ & $\begin{array}{l}\text { No laws, No generalizations } \\
\text { Too restrictive a view }\end{array}$ \\
\hline SCHAETER & $\begin{array}{l}\text { Exeptionalism in Geog- } \\
\text { raphy }\end{array}$ & $\begin{array}{l}\text { Spatial introduction } \\
\text { Spatial organization. } \\
\text { Nomothetic appeal }\end{array}$ & $\begin{array}{l}\text { Location } \\
\text { Flows } \\
\text { Distribution } \\
\text { Settlement }\end{array}$ & $\begin{array}{l}\text { Mathematic } \\
\text { Statistical methods } \\
\text { Scientific methods }\end{array}$ & $\begin{array}{l}\text { The method is too res- } \\
\text { trictive and valueless }\end{array}$ \\
\hline
\end{tabular}

